\title{
ŹRÓDLA DO BADAŃ NAD RELIGIJNOŚCIĄ WIERNYCH W OKRESIE PO II WOJNIE ŚWIATOWEJ POCHODZĄCE Z PARAFIALNYCH ARCHIWÓW
}

Wbrew pozorom, źródła do niniejszego tematu są obfite, choć rozproszone. Pozostaje problem dotarcia, uporządkowania i zajęcia wobec nich stosunku. Temat niniejszy będzie ograniczony do archiwaliów parafialnych, które zawierają mnóstwo materiału do interesującej nas problematyki i sa zasadniczymi źródłami do badań powstałymi w terenie. Parafia zarazem jest bezpośrednim miejscem kształtowania się i realizacji życia religijnego wiernych. Wartość tych archiwaliów dla tematu nas interesującego z okresu PRL jest tym większa, gdyż bogate w przeszłości formy życia religijnego realizowanego w strukturach diecezjalnych, czy ponaddiecezjalnych w postaci np. bractw i organizacji religijnych i inna działalność zewnętrzna Kościoła przy czynnym udziale świeckich uległy po II wojnie światowej zahamowaniu. Odtąd życie religijne wiernych realizowało się głównie w parafiach wokół ich podstawowych funkcji duszpasterskich. Mimo nawet najbardziej restrykcyjnej wobec Kościola polityki państwa, w parafiach odbywały się choć w skromniejszym wymiarze: głównie Służba Boża, administracja Sakramentów św., kaznodziejstwo, katechizacja, duszpasterstwo chorych, które kształtowały religijność wiernych.

Autor w niniejszym opracowaniu pragnie zwrócić uwagę na szczególną wartość parafialnych archiwów dla badań w powyższym temacie. Problematyka przedstawiona będzie na przykładzie historycznej już diecezji katowickiej, na podstawie sondażowej analizy zawartości archiwaliów 13 jej parafii z interesującego nas okresu: 7 miejskich ${ }^{1}$ oraz 6 wiej-

${ }^{1}$ Parafie: obecna katedralna św. Mikołaja w Bielsku Białej, w Katowicach św. Józefa, Przemienienia Pańskiego i św. Szczepana, w Pszczynie Wszystkich Świętych, w Tychach i Chorzowie Starym p.w. św. Marii Magdaleny. 
skich $^{2}$. Zawartość przebadanych archiwów jest raczej duża. Tylko nieliczne posiadają skromne archiwalia, ograniczające się do podstawowych. Większość jednak posiada dobrze oraz przejrzyście opracowane i opisane teczki, skoroszyty oraz inne oprócz metrykalnych księgi. Niektóre parafie posiadaja z interesującego nas okresu dziejów imponujące archiwa, zawierające skrzętnie gromadzoną dokumentację z poszczególnych lat, podzieloną według podziałów tematycznych ${ }^{3}$. Wiejska parafia p.w. św. Bartlomieja w Hażlachu oprócz ksiag metrykalnych posiada 75 teczek obejmujących 24 tytuly według schematu: A - sprawy ogólne parafii, B - duszpasterstwo ogólne, C - duszpasterstwo specjalistyczne i stanowe, D - sprawy małżeńskie, E - Służba Boża, F duszpasterze i służba Kościelna. Archiwum parafii miejskiej św. Józefa w Katowicach Załężu posiada 220 segregatorów uszeregowanych w 75 zespolach tematycznych w systemie literowym oraz dziesiętnym i $25 \mathrm{ksiag}$ oprócz metrykalnych. Archiwalia nas interesujące zawarte są w następujących zespolach; A3 - władze nadzorcze, A4 - statystyka, A5 - kroniki, A6 - messalia, D1 - służba Boża i nabożeństwa nadzwyczajne, D3 - sprawy małżeńskie; E1 - duszpasterstwo ogólne, E2 - duszpasterstwo specjalistyczne, E3 - duszpasterstwo nadzwyczajne E4 - duszpasterstwo stanowe, E5 - stowarzyszenia kościelne, E6 - akcja oświatowa i biblioteka parafialna, E7 - działalność charytatywna. Wszystkie badane archiwa posiadaja przejrzyste katalogi i pozwalaja na latwy do nich wgląd. Ówczesny biskup katowicki ks. Stanisław Adamski wydał 25 I 1961 r. odpowiednie rozporządzenie adresowane do proboszczów jego diecezji nakazujące im gromadzenie i przejrzyste opracowanie bieżacych historycznych dokumentów ${ }^{4}$. Katalogi archiwów posiadaja pieczatki potwierdzające wizytacje kanoniczne m.in. ich zawartości. Różna zawartość analizowanych archiwów parafialnych; od skromnych ograniczajacych się do zgromadzonych podstawowych ksiag oraz teczek akt po bogate archiwalia przedstawia różne podejście proboszczów po II wojnie światowej wobec niniejszego problemu.

${ }^{2}$ Parafie św. Bartłomieja w Hażlachu, Narodzenia św. Jana Chrzciciela w Rudzicy, św. Stanisława w Starym Bielsku i św. Józefa w Zabrzegu na Śląsku Cieszyńskim i Przemienienia Pańskiego w Bobrownikach na Śląsku Górnym.

${ }^{3}$ Parafie wiejska w Hażlachu k. Cieszyna i miejskie św. Szczepana i św. Józefa w Katowicach.

${ }^{4}$ Katalogi archiwów parafialnych św. Mikolaja w Bielsku i św. Szczepana w Katowicach posiadają dołączony tekst niniejszego rozporządzenia biskupa ordynariusza. 


\section{SZCZEGÓŁOWA PROBLEMATYKA ZAWARTA WE WSZYSTKICH ARCHIWACH PARAFIALNYCH}

Poszczególne parafie posiadają bardziej lub mniej dokładne statystyki dotyczące szczegółów ich życia, zawierające zestawienia w temacie życia m.in. religijnego, moralnego wiernych (np. komunikantes, dominikantes, posługę poszczególnych sakramentów świętych oraz ich przyjmowanie przez wiernych, pogrzeby, duszpasterstwo chorych i inne) pozwalajace prześledzić poszczególną interesująca historyka problematykę na przestrzeni lat. Archiwa te posiadaja poszczególne roczniki ogłoszeń parafialnych, gromadzonych w różnym stopniu staranności, w niektórych latach mające luki. We wszystkich parafiach istnieja kartoteki parafialne posiadajace dane m.in. od $1950 \mathrm{r}$. których treść uzupełniana byla na bieżąco przez kolejnych duszpasterzy, dotycząca m.in. spraw; małżeństw sakramentalnych i niesakramentalnych, rozbitych rodzin, dzietności rodzin, zawodów, informacje szczegółowe na temat stosunku poszczególnych wiernych wobec spraw wiary, praktyk religijnych, ruchu ludności na terenie parafii. Starsze zachowane kartoteki zawierają też adnotacje dotyczące gorliwości wiernych w spelnianiu obowiązku Komunii św. wielkanocnej ${ }^{6}$. Archiwa kilku parafii posiadają osobne teczki dotyczące corocznej kolędy zawierające dalsze szczegółowe informacje na temat wiernych. Protokoly wizytacji dziekańskich oraz generalnych biskupich maja wszystkie parafie, zawierające uwagi na temat poszczególnych ich problemów. Podobnie zachowane w różnym stopniu skompletowania porządki nabożeństw, poza duszpasterstwem pozwalają też zbadać problematykę praktykowanej pobożności wiernych. Niektóre parafie posiadają osobne teczki dotyczące nabożeństw paraliturgicznych odbywanych w ich kościolach ${ }^{7}$. Kroniki, prowadzone bardziej lub mniej sumiennie posiadaja wszystkie badane parafie. W diecezji katowickiej obowiązywal centralny system przyjmowania przez kancelarię parafialną intencji odprawianych w kościołach parafialnych Mszy św. Od przynajmniej 30 lat zachowane sa kompletne księgi odprawianych intencji. Jedna $\mathrm{z}$ nich posiada ich komplet od $1930 \mathrm{r}^{8}$. W większości parafii, zwłaszcza na

${ }^{5}$ Archiwum parafii św. Mikołaja w Bielsku.

${ }^{6}$ Zachowane w parafii św. Józefa w Katowicach kartoteki posiadają coroczne adnotacje dotyczące niniejszego problemu do początku lat 1990. Statystyka porównująca dane od ok. 1960 r. dotyczące spowiedzi wielkanocnej wskazuje zbieżność ze statystyką dominikantes, powstałą z 2 krotnego w roku liczenia wiernych obecnych na niedzielnej mszy św. przekazywaną do Kurii.

${ }^{7}$ Wiejska w Rudzicy i miejska św. Józefa w Katowicach.

${ }^{8}$ Archiwum parafii św. Józefa w Katowicach. 
Śląsku Cieszyńskim istnieja przynajmniej od 1960 r. księgi tematów głoszonych kazań, pozwalające odtworzyć problematykę na która zwracali duszpasterze uwage ${ }^{9}$. Wszystkie posiadają teczki poświęcone rekolekcjom i misjom parafialnym. W niektórych prowadzono odrębnie ${ }^{10}$, zwłaszcza przed $1980 \mathrm{r}$. księge uczestników stanowych dni skupienia ${ }^{11}$. Archiwa parafialne zawierają też teczki dotyczące duszpasterstwa. Niektóre wyszczególniały duszpasterstwo stanowe $^{12}$ oraz specjalistyczne np. gluchoniemych ${ }^{13}$. Wartościowego materiału źródłowego na temat losów katechizacji szkolnej i przykościelnej od 1945 roku do współczesności dostarczają teczki akt odrębnie poświęcone tej problematyce prowadzone prawie we wszystkich przebadanych parafiach. W niektórych, zwłaszcza miejskich istnieja kompletne dzienniki oraz kartoteki katechizowanych dzieci oraz młodzieży oraz uczestniczących w katechizacji dorosłych $^{14}$. Czlonkostwo wiernych $w$ radach parafialnych i duszpasterskich (zwłaszcza po Soborze Watykańskim II) jest znakiem czynnego ich zaangażowania w sprawy Kościoła lokalnego w parafii. Wszystkie posiadają osobne teczki, zawierające w swojej treści problematykę duszpasterską na ich posiedzeniach rozpatrywana. Powołania kapłańskie i zakonne ciesząc się zainteresowaniem Kościoła są ilustracją żywotności parafii, nawet posiadających skomplikowane problemy duszpasterskie ${ }^{15}$. Na ten temat osobno potraktowany posiadają teczki wszystkie parafie. Material uzupełniający dostarczają też dobrze zredagowane niektóre schematyzmy diecezjalne, zwlaszcza z lat 1970, 1984, 1993, i 1995 podające przy parafiach nazwiska księży z nich pochodzących. Skrupulatnie gromadzone i przechowywane akta zawieranych małżeństw; protokoly przedmałżeńskie, dyspensy, zapowiedzi pozwalają prześledzić religijność wiernych w powyższym kontekście; zwłaszcza zidentyfikować fakty przeszkód i wszelkich nieprawidłowości małżeńskich oraz ich częstotliwości. sku Białej

${ }^{9}$ Archiwa parafii w Hażlachu, Rudzicy, Zabrzegu i katedralnej św. Mikolaja w Biel-

${ }^{10}$ Archiwa parafialne św. Mikołaja w Bielsku i w Hażlachu.

11 Wykazy uczestniczących w dniach skupienia w latach 1969-1975 w parafii św. Szczepana w Katowicach.

${ }^{12}$ Archiwa parafii wiejskich w Hażlachu i Rudzicy oraz miejskiej św. Józefa w Katowicach.

${ }^{13}$ Archiwa parafii św. Mikołaja w Bielsku i św. Józefa w Katowicach.

${ }^{14}$ Archiwa parafii św. Józefa i św. Szczepana w Katowicach i św. Marii Magdaleny w Tychach.

${ }^{15}$ Parafia św. Józefa w Katowicach położona jest w dzielnicy zamieszkałej przez pokaźny procent ludności z tzw. marginesu społecznego. Z okresu po II wojnie światowej pochodzi z niej 21 księży diecezjalnych i zakonnych. 


\section{KSIĘGI, W TYM METRYKALNE ORAZ ICH WARTOŚĆ DLA BADAŃ}

Księgi te pozwalają też odtworzyć interesująca nas problematykę; np. przy chrztach dzietność rodzin, problemy małżeństw sakramentalnych, niesakramentalnych, dzieci pozamałżeńskich, księgi zmarłych, obok innych zawieraja głównie informacje na temat stosunku wiernych wobec Boga $w$ obliczu własnej śmierci w związku $z$ adnotacjami dotyczacymi przyjęcia sakramentu namaszczenia chorych. Wszystkie księgi metrykalne, po żmudnej kwerendzie źródłowej i sporządzeniu odpowiednich statystyk dotyczących poszczególnych lat dają cenny przegląd sytuacji w wyżej wymienionej problematyce. Oprócz powyższych, parafie posiadają komplety ksiag; dzieci przystępujacych do I Komunii św., oraz w parafiach gdzie taka byla: wczesnej Komunii ${ }^{16}$, księgi bierzmowanych, chorych rejestrujące odwiedziny chorych przez duchownych ze sakramentalną posługą. O wartości ostatniej świadczą zachowane w katedrze lwowskiej obrządku lacińskiego księgi chorych z lat 1974-1990, które zarazem są dokumentem rzeczowym życia tamtejszego Kościoła z czasów istnienia ZSRR, zarazem wyjątkowej gorliwości jej duszpasterza z tamtych lat ś.p. o. biskupa Rafała Kiernickiego ${ }^{17}$, którego szczególnym przedmiotem opieki byli chorzy, kalecy i w podeszłym wieku. Z tego okresu zapisanych jest tam rocznie 2000-3000 odwiedzin w oddaleniu do ok. $150 \mathrm{~km}$ od Lwowa.

\section{SZCZEGÓŁOWA PROBLEMATYKA Z POSZCZEGÓLNYCH PARAFII}

Po skasowaniu przez państwo w 1950 r. Caritas Kościelnej i innych form zorganizowanej pomocy charytatywnej ${ }^{18}$, w niektórych parafiach przetrwały ${ }^{19}$,

${ }^{16}$ W parafiach św. Mikolaja w Bielsku i św. Józefa w Katowicach.

17 O. bp Rafal Kiernicki (1912-1995) OFM Conv. urodził się 3 V 1912 r. w Kułaczkowcach k. Kołomyi w archidiecezji lwowskiej. Święcenia kapłańskie otrzymal 29 VI 1939 r. W czasie II wojny światowej oprócz duszpasterstwa opiekował się harcerstwem, będąc zaangażowany (ps. Dziunio) w strukturach $\mathrm{AK}$, pełnił w niej funkcję oficera odpowiedzialnego za lączność w lwowskim okręgu. Po akcji „Burza” został wraz z dowództwem lwowskiej AK w 1944 r. aresztowany przez radzieckie władze. Po 6 miesiącach więzienia i spędzonych 3 i pół roku w łagrach w Charkowie i Riazaniu wrócil do Lwowa w 1948 roku i odtąd nieprzerwanie pełnil duszpasterstwo w katedrze lwowskiej obrządku łacińskiego. W 1990 r. Ojciec Święty podniósł go do godności infułata. Następnie 15 I 1992 r. mianował go biskupem pomocniczym lwowskiego arcybiskupa obrządku łacińskiego. Zmarł 23 XI 1995 r. i spoczal w katedrze lwowskiej w krypcie Chrystusa Ukrzyżowanego.

${ }_{18}$ Andrzej Grajewski, Wygnanie, Katowice 1995, s. 81; Historia Kościola w Polsce Pod red. B. Kumora, Z. Obertyńskiego. T. 2, cz. 2. Poznań 1979, s. 203; Andrzej Micewski, Kardynal Wyszyński. Prymas i maż stanu. Paryż 1982, s. 68-70; Peter Raina, Kardynal Wyszyński. T. 1, Droga na stolicę prymasowska. Warszawa 1993, s. 186-187.

${ }^{19}$ W parafiach św. Józefa i św. Szczepana w Katowicach. 
w innych po $1960 \mathrm{r}$. odradzały się tzw. parafialne zespoly charytatywne w których wierni pod kierownictwem proboszczów, najczęściej panie spieszyli z pomoca chorym i starszym oraz zaradzali potrzebom socjalnym. W parafiach gdzie istniały takie, archiwa posiadają obfitą dokumentację na ten temat, zgromadzona $w$ osobnych teczkach. Podobnie po likwidacji przez państwo wszelkich stowarzyszeń religijnych, pozostały wiernym nieliczne czysto dewocyjne inicjatywy; trzecie zakony, różne rodzaje wspólnot różańcowych, czcicieli Serca Pana Jezusa, Matki Boskiej i innych świętych, apostolstwa modlitwy, Komunii św. Wynagradzającej, Nocnej Adoracji i inne. Ślady ich działalności istnieją w postaci ksiąg ich czlonków, zamawianych przez nich intencji Mszy św. czy tylko ksiag pamiątkowych. Organizowana przez Kościół akcja trzeźwościowa po 1970 r., najcz̨̧ściej jako ratunek wiernych przed zorganizowanym przez państwo rozpijaniem Narodu, zwlaszcza po stanie wojennym $1981 \mathrm{r}$. posiada swój trwały ślad w postaci ksiąg trzeźwości, w których wierni wpisywali deklarację trzeźwości czy abstynencji. $\mathrm{O}$ wadze niniejszego problemu świadczy fakt, że założyciel Ruchu Światło Życie ks. Franciszek Blachnicki na początku lat 1960 otrzymał w Sądzie Wojewódzkim w Katowicach wyrok więzienia za utworzenie Krucjaty Trzeźwości, nazwanej w sądowym orzeczeniu jako antypolska i kontrrewolucyjna organizacja ${ }^{20}$. Wszystkie badane archiwa posiadają niniejsze księgi. Część terytorium historycznej diecezji katowickiej jest ziemia pogranicza katolicko - luterańskiego. Parafie Śląska Cieszyńskiego posiadają osobne teczki akt poświęconych problematyce ekumenizmu na ich terenie ${ }^{21}$. W latach 1972-1975 diecezja katowicka odbyła I Synod Diecezjalny ${ }^{22}$. W jego ramach w poszczególnych parafiach istniały zespoły synodalne, których problematyce poświęcone sa istniejące teczki akt w 2 parafiach ${ }^{23}$. Archiwum parafii Wszystkich Świętych w Pszczynie posiada 2 zeszyty zawierajace zapisy prenumeraty przez wiernych pism katolickich $z$ lat $1970-1980$.

Oprócz powyższych bogate archiwum parafii św. Józefa w Katowicach posiada osobno wyszczególnione następujace akta. 3 teczki; apostaci i konwertyci (z lat 1901-1990) zawieraja dokumenty apostazji niektórych parafian zarażonych ideologią nazistowską w czasie wojny, z powodu której występowali z Kościoła, oraz zawiadomienia przysyłane po wojnie z Niemiec na temat powrotu niektórych z nich na Jego łono. Podobnie w związku z fala emigracji ze

${ }^{20}$ Archiwum Archidiecezji Katowickiej, (bez sygn.:) Akta Personalne: Ks. Franciszek Blachnicki, vol. 2, k. 322-336 (Akt oskarżenia prokuratury wojewódzkiej w Katowicach).

${ }^{21}$ Archiwa parafii św. Mikołaja w Bielsku, Hażlachu i Rudzicy na Śląsku Cieszyńskim i św. Marii Magdaleny w Tychach na Gómym Śląsku.

${ }^{22}$ Wiara modlitwa $i$ życie w Kościele Katowickim. Uchwaty I Synodu Diecezji Katowickiej. Katowice-Rzym 1976.

${ }^{23}$ Archiwa parafialne św. Mikołaja w Bielsku i w Hażlachu. 
Śląska do Niemiec po 1980 r., niektórzy z parafían w miejscu nowego osiedlenia, w związku z obowiązującym tam podatkiem kościelnym opuszczali Kościół. Teczki te posiadaja dosyć liczne wnioski Centrali Ksiag Metrykalnych w Monachium o wpisanie w księdze urodzeń faktu apostazji. Sprawy małżeńskie w niniejszym archiwum rozbite są na mniejsze zespoły tematyczne; konkubinaty, malżenstwa cywilne, rozwody, licencje, dyspensy. Działy duszpasterstwa nadzwyczajnego i specjalnego posiadają osobne podzespoły tematyczne; pierwszy (tridua, rekolckcje, misje, pielgrzymki, uroczystości parafialne, odpusty) i drugi (duszpasterstwo niewidomych, gluchoniemych, wojskowych, alkoholików oraz małżeństwa mieszane). Na uwage zasługują 2 teczki, związane z losami ludności autochtonicznej w czasie II wojny Swiatowej oraz po jej zakończeniu w związku z nastaniem władzy ludowej; polegli na wojnie 1939-1945 oraz druga, jeńcy wojenni i deportowani na Sybir 1939-1949. Oprócz wcześniej wspomnianych przy innych parafiach ksiag wpisów i pamiatkowych, archiwum to posiada: spis czlonków Adoracji Nocnej z lat 1965-1980, ofiarodawców wotywnych z lat 1962-1974, ofiary składane na kościół z lat 1971-1980, oraz regularnie prowadzona w latach 1965-1984 kronika coroczncj pieszej pielgrzymki młodzieży na Jasną Górę.

\section{INNE POZA ARCHIWALNE ŹRÓDLA.}

Ważnym uzupełnieniem treści źródeł archiwalnych dotyczących życia religijnego wiernych na terenie parafii jest ankieta przeprowadzona wśród uczestników, świadków przedstawianej problematyki. Dobrze zredagowana, zawierająca kilkadziesiąt konkretnych pytań kierowanych do ankietowanych osób, przeprowadzona po wyczerpującej kwerendzie źródłowej, przy równoczesnym zachowaniu obiektywizmu wnosi wiele nowych szczegółów pomagajacych przedstawić rzeczowo omawianą problematykę ${ }^{24}$. Jej wartość jest tym większa, gdyż skutek niebezpieczeństwa inwigilacji przez służbę bezpieczeństwa oraz obaw ludzi przed ujawnianiem swojego czynnego angażowania się w życie Kościoła, interesująca tematyka poza archiwami kościelnymi nie była rejestrowana. W prasie zwłaszcza pozakonfesyjnej, gdzie obowiązywało na-

${ }^{24}$ Kilka tytułów prac magisterskich, powstałych w ramach seminarium $\mathrm{z}$ historii Kościoła na Wydziałach Teologicznych KUL i ATK, dotyczących życia religijnego i duszpasterstwa parafii z okresu będącego przedmiotem niniejszego tematu w których wykorzystano ankiety i ocenione były na bardzo dobry: Zbigniew Brzózka, Praca duszpasterska ks. Józefa Kuczery w parafii pszczyńskiej (1941-1989). Lublin 1993; Józef Piesiur, Życie religijne w parafii pszczyńskiej w latach 1922-1972. Warszawa, 1989; Janina Przebindowska, Powstanie i rozwój parafii Podwyższenia Krzyża Śsiętego i Świętego Herberta w Katowicach (1982-1993). Lublin 1995. 
rzucone przez cenzurę embargo, dla niej też nie było miejsca. Oprócz powyższych źródłami uzupelniającymi są pisane, następnie publikowane wspomnienia duchownych, bądź świeckich związanych z duszpasterstwem parafialnym. Szczególnie cenne jest gdy sa wydane krytycznie przez fachowca historyka weryfikującego przedstawiana przez autora problematykę. Przykladem wartościowych wspomnień wprawdzie wykraczających czasowo i terytorialnie poza temat, opublikowanych krytycznie sa wspomnienia ks. Teofila Skalskiego. Autor ks. infułat Skalski wikariusz generalny i administrator apostolski części diecezji łucko-żytomierskiej pozostałej po Rewolucji Październikowej w granicach ZSRR na przykładzie swoich wspomnień przedstawił szczególowo udokumentowaną historię Kościoła w pierwszych latach ZSRR zwłaszcza w Kijowie, gdzie był proboszczem tamtejszej parafii p.w. św. Aleksandra. Natomiast wydawca przez staranne edytorskie wydanie i obfita dokumentacje omawianych przez autora faktów, zawartą w licznych przypisach, uczynil z niniejszych wspomnień wiarygodne wydawnictwo źródłowe dotyczące dziejów Kościola w ZSRR na początku jego istnienia ${ }^{25}$. Historyczna już diecezja katowicka, której dotyczyły głównie niniejsze omawiane źródła parafialne posiada opracowanie dotyczące jej życia w okresie największego terroru stalinowskiego p.t. „Wygnanie” autorstwa Andrzeja Grajewskiego. Pozycja ta oparta jest na dokumentach archiwalnych, zwłaszcza Kurii Diecezjalnej, ankiecie przeprowadzonej wśród ludzi, którzy mieli na ten temat do powiedzenia oraz archiwum centralnego UOP, do którego autor miał dostęp na wniosek katowickiego arcybiskupa ks. dra Damiana Zimonia. Zaopatrzona w indeksy rzeczowy i nazwisk umożliwiające się po niej poruszać jest w zamiarze autora i wydawców rodzajem rozliczenia się Kościoła lokalnego z trudna przeszłością zwlaszcza w czasie wygnania z diecezji jej biskupów w latach 1952-1956. Książka ta przedstawia struktury diecezji, postawy jej kapłanów i wiernych wobec państwa i narzuconych jej administratorów ${ }^{26}$.

Tytułem konkluzji niniejszego przedłożenia, autor pragnie zwrócić uwagę na szczególną wartość archiwów parafialnych dla badań nad najnowszymi dziejami Kościoła w Polsce, których historycy Kościoła nie mogą lekceważyć. Podejmowane jako tematy prac magisterskich; dzieje parafii po II wojnie światowej, zwłaszcza ich duszpasterstwa oraz życia religijnego nie sa bezprzedmiotowe. Sumienna oraz fachowa kwerenda źródłowa w nich przeprowadzona, uzupełniona ankieta daja cenne opracowania interesującego nas tematu w terenie. W związku ze zróżnicowaniem zawartości sondowanych archiwów parafialnych (archiwa obfite w dokumentację i skromniejsze ograni-

${ }^{25}$ Teofil Skalski ks., Terror i cierpienie. Kościól katolicki na Ukrainie 1900-1932. Wyd. Józef Wolczański. Lublin-Rzym-Lwów 1995.

${ }^{26}$ Andrzej Grajewski, Wygnanie. Katowice 1995. 
czające się do podstawowych materiałów) rodzi się kolejny postulat wyczuwania duszpasterzy tworzących dokumenty i odpowiedzialnych za gromadzenie i zabezpieczanie ich, na szacunek wobec wytworzonych na terenie parafii przez siebie i poprzedników nawet najdrobniejszych archiwaliów oraz zobowiązywanie do troski o zabezpieczanie ich w parafialnych archiwach przed zniszczeniem. 